\title{
Analisis Kemampuan Literasi Sains Siswa SMP Ibrahimy 3 pada Isu Pencemaran Lingkungan di Pelelangan Ikan Mimbo
}

\author{
Nikmatin Mabsutsah $^{1)^{*}}$, Sudarti $^{1)}$, Wachju Subchan ${ }^{1)}$ \\ ${ }^{1)}$ Universitas Jember \\ *nikmatinmabsutsah@gmail.com
}

Abstrak: Isu lingkungan di pelelelangan ikan Mimbo perlu adanya pendekatan secara ilmiah, salah satu langkahnya adalah dengan membuat siswa melek sains yaitu kemampuan memahami isu lingkungan, mengkomunikasikan, dan mengaplikasikan konsep lingkungan kedalam dunia nyata. Tujuan dari penelitian ini adalah mengindentifikasi isu lingkungan dan menganalisis kemampuan literasi sains siswa pada isu lingkungan di pelelangan ikan Mimbo, Situbondo. Penelitian ini dilakukan di SMP Ibrahimy 3, Kabupaten Situbondo. Metode penelitian yang digunakan pada penelitian ini adalah metode penelitian deskriptif kualitatif. Subjek penelitian adalah siswa kelas VII SMP dengan jumlah 200 siswa. Dengan demikian kemampuan literasi sains siswa berdasarkan literasi sains memiliki presentase nilai rata-rata aspek konten (55,9\%), aspek proses (54.70\%), dan aspek konteks $(57,4 \%)$. Apabila ditinjau secara keseluruhan dari hasil penjabaran rata-rata nilai presentase menunjukkan bahwa kemampuan literasi sains siswa masih katogori rendah.

Kata kunci: Isu Lingkungan, Literasi Sains, Pelelangan Mimbo

\section{Pendahuluan}

Bahaya pencemaran lingkungan masih belum banyak diketahui oleh masyarakat Indonesia, pencemaran dapat berupa pencemaran air, tanah maupun udara. Salah satu penyebab pencemaran yaitu sampah, menurut (Jambeck, Geyer, J.R.R., Wilcow, C., Siegler, T.R., Perryman, M., Andrady, A., Narayan, R. \& Law, 2015) Indonesia menempati posisi kedua dengan sampah terbanyak didunia yaitu dengan adanya sampah 0,48 - 1,29 juta ton per tahun. Data yang dihimpun (Kementerian Lingkungan Hidup dan Kehutanan, 2017) menunjukan pencemaran sampah yang mengkhawatirkan di wilayah pesisir pantai. Secara nasional, jumlah sampah plastik sebanyak \pm 488 ribu ton. Daerah Labuan Bajo, Kabupaten Manggarai Barat memiliki total sampah plastik sebanyak $46,45 \%$ dan busa plastik sebanyak 0,83\% dari jumlah seluruh sampah yang ditemukan. Menurut NOAA (National Oceanic and Atmospheric Administration), sampah laut didefinisikan sebagai benda padat yang dihasilkan oleh manusia, baik secara langsung maupun tidak langsung, sengaja maupun secara tidak sengaja dibuang di dalam lingkungan laut (NOAA, 2013).

Sampah yang ditemukan di laut dapat berupa sampah plastik, styrofoam, logam dan lain sebagainya. Menurut (Mulu et al., 2020)sampah plastik yang masuk ke laut semakin lama akan terfragmentasi menjadi partikel yang lebih kecil, yaitu mikroplastik. Mikroplastik adalah butir-butir plastik, serat, dan fragmen yang berukuran $<5 \mathrm{~mm}$ (Pham, Clark, \& Li, 2021). Mikroplastik adalah polutan yang sangat memprihatinkan karena potensi risikonya terhadap organisme dan ekosistem. Mikroplastik tersebar luas di ekosistem darat dan perairan dan dapat ditemukan bahkan di Antartika dan sedimen laut dalam (Ahmad, M., J. L. Li1, P. D. Wang, \&W. N. Hozzein, 2020).Berdasarkan penelitian (Suprijanto, Senduk, \& Makrima, 2021) mikroplastik di temukan pada cumi - cumi (Loligo sp.) dan ikan kembung (Rastrelliger sp.) berupa nitrile dan nylon. Cumi - cumi dan ikan kembung merupakan salah satu ikan yang bernilai ekonomis bagi masyarakat pesisir. Selain plastik, berdasarkan penelitian (De-la-Torre, G.E., Dioses-Salinas, D.C., Castro, J.M., Antay, R., Fernández, N.Y., EspinozaMorriberón, D., \& SaldañaSerrano, 2020) menemukan dominansi styrofoam di pantai yang dekat dengan wilayah perkotaan akibat tingginya penggunaan alat makan sekali pakai berbahan styrofoam. Penelitian (Putra, B. A., A. Santoso, 2019) menyatakan kandungan logam Zn pada kolom air di Teluk Awur sudah melebihi baku mutu yang ada, sehingga lamun Enhalus acoroides di periaran Jepara telah tercemar logam. 
Daur ulang sampah yang terbatas dan kurangnya peraturan yang membatasi sampah plastik, plastik (nano dan mikroplastik) telah mencemari perairan, daratan, dan lingkungan atmosfer di seluruh dunia. Plastik mencemari lautan, laut, sungai, dan danau bahkan mencapai laut es Arktik (Peeken I, Primpke S, Beyer B, Gütermann J, Katlein C, 2018). Oleh karena itu, penelitian ini melakukan pengamatan terlebih dahulu di salah satu dusun wilayah pesisir yang menjadi tempat pelelangan ikan. Dusun yang terletak di kawasan pesisir Desa Sumberanyar Kecamatan Banyuputih Kabupaten Situbondo Provinsi Jawa Timur salah satunya adalah Dusun Mimbo. Hasil pengamatan lingkungan yang dilakukan disekitar Pelelangan ikan Mimbo, kondisinya sangat memprihatinkan. Sampah rumah tangga yang dihasilkan, biasanya dibuang dan berserakan begitu saja di sekitar pantai. Sampah-sampah yang berserakan tersebut, hanyut dan terbawa arus ke laut lepas. Kondisi ini semakin parah ketika jumlah kunjungan wisatawan lokal meningkat. Selain itu, udara sekitas kawasan pelelangan ikan di Mimbo juga sangat bau sebab bangkai ikan dan sisa air cucian ikan. Sehingga dapat disimpulkan bahwa kawsan sekitar pelelangan ikan di Mimbo telah tercemar, baik pencemaran air, pencemaran tanah, maupun pencemaran udara. Pencemaran lingungan pada kawasan mimbo jika terus berlangsung maka akan berbahaya bagi kehidupan biota dan masyarakat di dusun Mimbo.

Permasalahan lingkungan tersebut berhubungan dengan generasi yang akan datang bagaimana menanggapi dan menyikapi isu lingkungan, salah satunya pada siswa SMP. Oleh karena itu, siswa SMP di sekitar pelelangan ikan Mimbo perlu dianalisis kemampuannya dalam membaca masalah ingkungan, salah satunya dengan literasi sains. Menurut (Sukib, Muti'ah, Siahaan, \& Supriadi, 2020) pemahaman siswa masih sangat rendah mengeai sampah mikroplastik, bahaya mikroplastik, kerugian nelayan dan pariwisata akibat sampah laut, dan dampak membuang sampah di sungai terhadap pencemaran laut. Sehingga perlu adanya peninjauan terkait pengetahuan anak mereka yang masih duduk dibangku sekolah. Salah satunya dengan menganalisis kemampuan siswa pada penguasaan konsep lingkungan dengan menggunakan literasi sains, sehingga siswa dapat melek sains pada permasalahan lingkungan yang ada di sekitar rumah mereka.

Literasi sains dibedakan dalam tiga dimensi yaitu: konten (pengetahuan sains), proses (kompetensi sains), dan konteks (aplikasi sains) (PISA, 2010). Pertama, dimensi konten. Konten sains merujuk pada konsep-konsep kunci dari sains yang diperlukan untuk memahami fenomena alam dan perubahan yang dilakukan terhadap alam melalui aktivitas manusia. Dalam hal ini PISA tidak secara khusus membatasi cakupan konten sains hanya pada pengetahuan yang menjadi kurikulum sains sekolah, namun termasuk pula pengetahuan yang diperoleh melalui sumber-sumber informasi lain yang tersedia. Kedua, dimensi proses. Dimensi proses mencakup komponen kompetensi sains. Ada tiga fokus penilaian dalam dimensi proses literasi sains yakni meliputi kegiatan: mengidentifikasi pertanyaan ilmiah, menjelaskan fenomena secara ilmiah dan menggunakan bukti ilmiah. Proses kognitif yang terlibat dalam kompetensi sains antara lain penalaran induktif/deduktif, berfikir kritis dan terpadu, pengubahan representasi, mengkonstruksi eksplanasi berdasarkan data, berfikir dengan menggunakan model dan menggunakan matematika. Proses inkuiri ilmiah merupakan proses ilmiah yang melibatkan kemampuan berpikir logis, kemampuan penalaran dan analisis kritis. Proses inkuiri ilmiah sangat relevan dengan hakikat sains (biologi) dan sekaligus sebagai salah satu karakteristik dalam pembelajaran sains. Kompetensi ilmiah yang diukur dalam dimensi proses literasi sains meliputi: 1) Mengidentifikasi pertanyaan ilmiah berhubungan dengan pertanyaan ilmiah, yaitu pertanyaan yang meminta jawaban berlandaskan bukti ilmiah dimana di dalamnya mencakup kemampuan individu dalam mengenali pertanyaan yang memungkinkan untuk diselidiki secara ilmiah berdasarkan situasi yang dikondisikan, kemampuan mencari informasi dan mengidentifikasi kata kunci serta mengenali fitur penyelidikan ilmiah. Misalnya: hal-hal apa yang harus dibandingkan, variabel apa yang harus diubah-ubah dan dikendalikan, informasi tambahan apa yang diperlukan atau tindakan apa yang harus dilakukan agar data relevan dapat dikumpulkan; 2) Menjelaskan fenomena secara ilmiah yaitu kemampuan menjelaskan fenomena secara ilmiah mencakup kompetensi dalam mengaplikasikan pengetahuan sains dalam situasi yang diberikan, mendeskripsikan fenomena, memprediksi perubahan, pengenalan dan identifikasi deskripsi, eksplanasi dan prediksi yang sesuai; 3) Menggunakan bukti ilmiah, yaitu kompetensi ini menuntut peserta didik memaknai temuan ilmiah sebagai bukti untuk suatu kesimpulan. Selain itu juga menyatakan bukti dan keputusan dengan kata-kata, diagram atau bentuk representasi lainnya. Dengan kata lain, peserta didik harus mampu menggambarkan hubungan yang jelas dan logis antara bukti dan kesimpulan atau keputusan. Ketiga, dimensi konteks. Dimensi konteks literasi sains menurut PISA mencakup berbagai bidang diantaranya: 1) bidang aplikasi sains meliputi penerapan sains dalam setting personal, sosial dan global seperti bidang: kesehatan; sumber daya alam; mutu lingkungan; bahaya; perkembangan mutakhir sains dan teknologi; 2) bidang penilaian (assessment) dimana butir-butir soal pada penilaian pembelajaran sains, 
menurut PISA berfokus pada situasi yang terkait pada diri individu, keluarga dan kelompok individu (personal), terkait pada komunitas (social), serta terkait pada kehidupan lintas negara (global).

Penelitian ini bertujuan untuk mengetahui kondisi lingkungan di daerah pelelangan ikan Mimbo dan mengidentifikasi kemampuan siswa melalui 15 soal pilihan ganda yang ditinjau dari 3 aspek literasi sains pada isu lingkungan yaitu: konten sains, proses sains, dan konteks sains. Penelitian ini merupakan penelitian deskriptif kualitatif yang menjelaskan kondisi lingkungan di pelelangan ikan Dusun Mimbo Desa Sumberanyar Banyuputih Situbondo, dan melibatkan 200 siswa kelas VII SMP Ibrahimy 3 Sukorejo Situbondo yang dipilih secara acak setiap kelas untuk test kemampuan literasi.

\section{Metode}

Teknik analisis data yang digunakan dalam penelitian ini adalah statistik deskriptif. Untuk mengetahui kemampuan literasi sains peserta didik dengan cara menganalisis data jawaban dari 15 soal pilihan ganda yang telah diberikan dengan memberikan skor menggunakan Microsoft Excel dan sebagian besar menggunakan rumus SUM dan AVERAGE untuk mencari presentase hasil kemampuan literasi sains dan menggunakan kunci jawaban pada tes yang telah dibuat oleh peneliti. Jawaban benar akan mendapat skor 1, jika salah atau tidak menjawab diberi skor 0. Menurut (Ali, 2013) kemampuan literasi sains dideskripsikan dengan menggunakan rumus sebaga berikut.

Tabel 1. Rumus sistematika kemampuan literasi sains

\begin{tabular}{ll}
\hline \multicolumn{1}{c}{ Skor Akhir $=\mathrm{R} / \mathrm{N} \times 100$} \\
\hline $\mathrm{S}=$ & Skor Akhir kemampuan literasi sains \\
$\mathrm{R}=$ & Skor jawaban benar \\
$\mathrm{N}=$ & Jumlah skor maksimum dari tes \\
\hline
\end{tabular}

Kemampuan literasi sains memiliki presentase nilai siswa yang dikelompokkan ke dalam kriteria hasil modifikasi dari (Purwanto, 2009) :

Tabel 2. Kriteria Presentase Penilaian Kemampuan Literasi Sains Siswa

\begin{tabular}{cc}
\hline Interval & Kriteria \\
\hline $86-100 \%$ & Sangat Tinggi \\
$76-85 \%$ & Tinggi \\
$60-75 \%$ & Cukup \\
$55-59 \%$ & Rendah \\
$\leq 54 \%$ & Sangat Rendah \\
\hline
\end{tabular}

\section{Hasil dan Pembahasan}

Berdasarkan hasil pengamatan yang dilakukan di Pelelangan Ikan Mimbo Desa Sumberanyar, Situbondo kondisi lingkungan di wilayah tersebut sangat memprihatinkan, dapat dilihat pada gambar. Pada gambar 1 menunjukkan perairan pantai pelelangan yang telah terkontaminasi dengan sampah sehingga menyebabkan pencemaran air. Macam-macam sampah yang mengkontaminasi daerah pesisir pantai antara lain yaitu plastik, styrofoam, pempers, kain, kayu, kardus, dan lain sebagainya. Plastik lebih mendominasi pencemaran di perairan pelelangan tersebut, dominasi pencemaran plastik diperairan laut terjadi sejak beberapa tahun silam, menurut (Eriksen M, Lebreton LCM, Carson HS, Thiel M, Moore CJ, 2014)di lingkungan laut, sampah plastik dapat ditemukan di dasar laut, permukaan dan garis pantai. Diperkirakan pada tahun 2014 bahwa setidaknya 5,25 triliun partikel plastik termasuk 35.500 metrik ton mikroplastik mengambang di laut.

Pada gambar 2 menunjukkan sampah juga bertumpukan pada daratan didekat pemukiman warga, sehingga menyebabkan pencemaran tanah. Sampah tersebut berasal dari limbah rumah tangga yang pemukiman mereka dekat dengan daerah pantai. Penyebab banyaknya limbah plastik dari limbah rumah tangga menurut (Alimba \& Faggio, 2019)plastik memiliki harga yang murah dan menarik sehingga 
menjadi esensial di setiap industri (pengemasan, konstruksi, transportasi, dll). Saat ini, hampir tidak mungkin menemukan barang bebas plastik. Plastik digunakan secara luas dalam kehidupan kita seharihari benda (kemasan, kosmetik, peralatan rumah tangga, peralatan listrik dan elektronik, furnitur, dll).

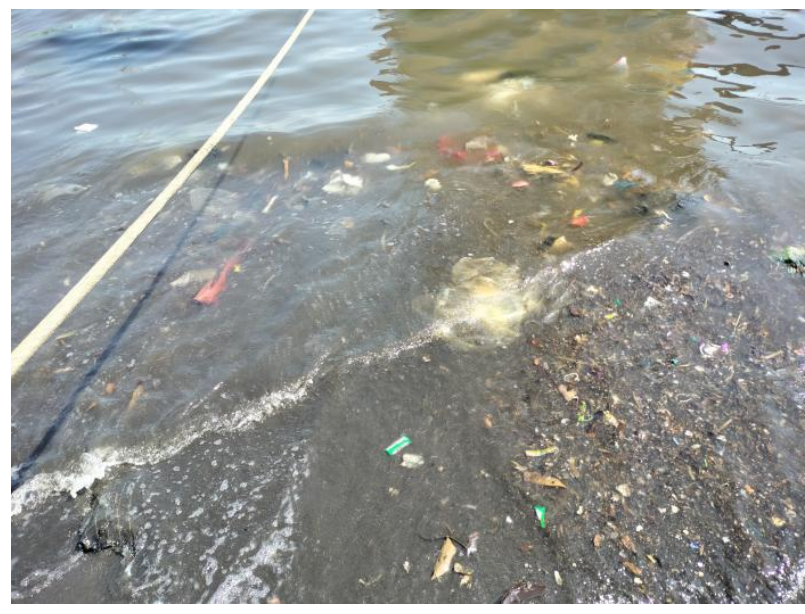

Gambar 1

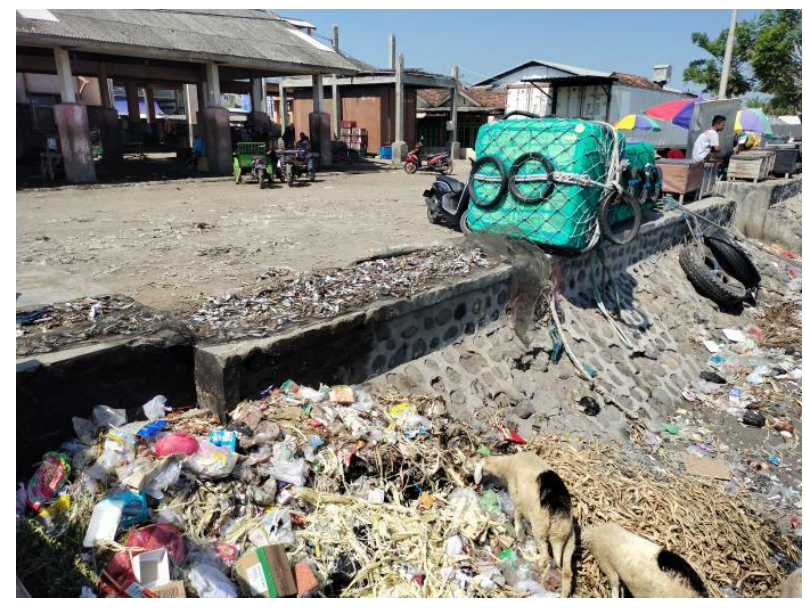

Gambar 3

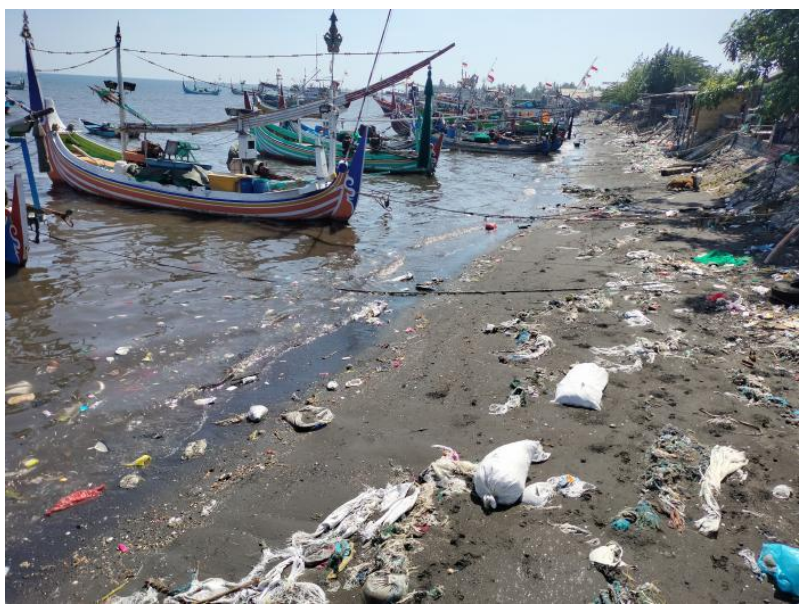

Gambar 2

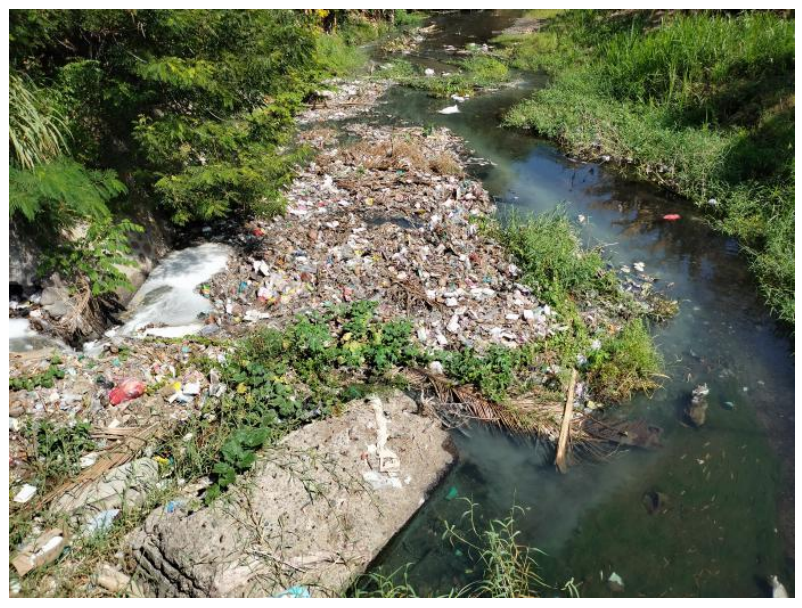

Gambar 4

Pada gambar 3 menunjukkan tumpukan sampah didekat pelelangan ikan. Sampah tersebut antara lain adalah pelastik, rumput kering, kardus styrofoam, botol kaca, dan lain sebagainya. Kemudian bangkai ikan yang di jemur didekat tumpukan sampah juga menyebabkan bau yang sangat menyengat di daerah pelelangan. Kondisi udara di daerah pelelangan dapat dinyatakan tidak sehat sebab bau bangkai ikan dan sisa-sisa air pelelangan ikan yang dibuang sembarangan. Menurut(Pamungkas, 2016)bahan organik yang terkandung dalam limbah cair dapat menghabiskan oksigen terlarut dalam limbah, serta menimbulkan bau yang tidak sedap, dan akan berbahaya apabila bahan tersebut merupakan bahan yang beracun.

Pada gambar 4 menunjukkan tumpukan sampah pada sungai yang bermuara pada laut Mimbo. Sampah tersbut berasal dari limbah rumah tangga, berupa sisa air sabun, deterjen, shampo, plastik, pempers, dan lain sebagainya. Berdasarkan pengamatan tersebut dapat disimpulkan bahwa kondisi sungai yang bermuara pada laut Mimbo telah tercemar. Sampah plastik juga mendominasi di sungai yang bermuara pada laut Mimbo, menurut (Wong, Löwemark, \& Kunz, 2020)dampak pencemaran mikroplastik di lingkungan air tawar sangat berkontribusi terhadap pencemaran mikroplastik di lautan.

Berdasarkan hasil pengamatan kondisi wilayah pelelangan ikan Mimbo, siswa diharapkan dapat melihat isu lingkungan secara ilmiah. Oleh karena itu, perlu melihat kemampuan siswa menjawab soal 
literasi sains yang memanfaatkan isu lingkungan setempat. Hasil literasi sains pada 200 siswa SMP Ibrahimy 3 dapat dilihat pada tabel 1 berikut ini.

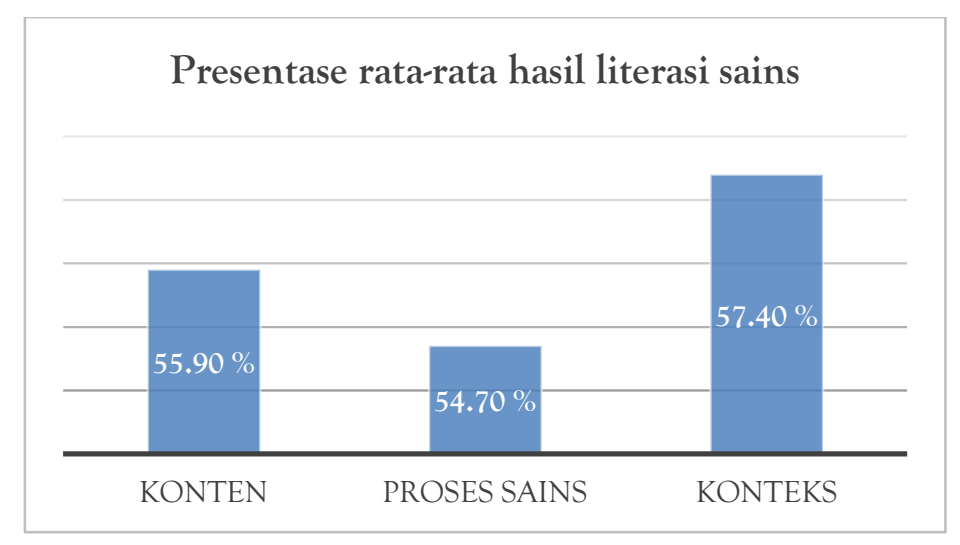

Gambar 5. Grafik presentasse rata-rata hasil literasi sains

Presentase hasil kemampuan literasi sains siswa SMP Ibrahimy 3 Sukorejo berdasarkan diagram di atas menunjukkan rata-rata hasil literasi yang masih rendah. Ditinjau dari aspek konten hasil literasi siswa yaitu 55,9 \% artinya penguasaan konsep sains pada isu lingkungan masih sangat rendah. Berikutnya ditinjau dari aspek proses sains hasil literasi siswa rata-rata $54.70 \%$ artinya pembelajaran pada proses sains masih rendah. Berikutnya ditinjau pada aspek konteks hasil literasi siswa yaitu 57,4\% artinya literasi siswa masih tergolong rendah.

Rendahnya hasil literasi sains pada siswa dapat dipengaruhi oleh beberapa faktor, salah satunya dalam proses pembelajaran. Menurut (Amalia \& Yulianti, 2018) ada beberapa hal yang menyebabkan rendahnya hasil capaian literasi sains siswa. Penyebab yang pertama tentang materi pelajaran yang belum pernah dipelajari sebelumnya oleh siswa sehingga siswa banyak mengalami kesulitan ketika menjawab soal-soal yang telah diberikan. Faktor selanjutnya yang menyebabkan rendahnya kemampuan literasi sains siswa yaitu kurangnya guru tentang cara membiasakan siswa serta mendukung siswa mengaplikasikan dan mengembangkan kemampuan literasi sains siswa dalam kehidupan sehari-hari dalam proses pembelajaran.

Berdasarkan hasil presentase di atas, perlu adanya integrasi isu lingkungan terhadap kurikulum dalam proses pembelajaran di sekolah, sehingga dapat meningkatkan literasi sains siswa pada isu lingkungan disekitar tempat tinggal mereka. Menurut (Putrawan, 2019) pengetahuan mengenai lingkungan dan isu-isu yang terjadi pada lingkungan yang dimilikinya, akan membuat seseorang memiliki kepekaan lingkungan yang lebih tinggi, sehingga memunculkan keinginan untuk bertindak. Dengan adanya kepekaan lingkungan, akan muncul seseorang juga akan menjadi lebih antusias untuk melakukan aksi-aksi penyelamatan lingkungan agar isu-isu yang terjadi dapat terselesaikan.

\section{Hasil Aspek Konten Sains}

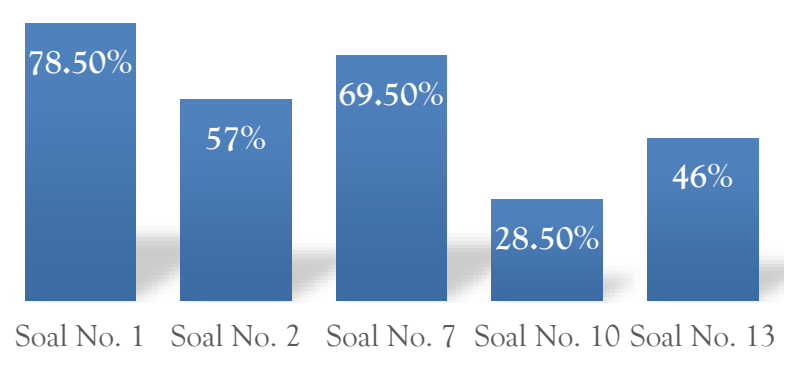

Gambar 6. Grafik presentase rata-rata hasil aspek konten sains setiap butir soal 
Berdasarkan hasil rata-rata aspek kontens sains tiap butir soal dapat dilihat pada gambar 6 . presentase hasil paling tinggi yaitu soal no.1 yang menanyakan tentang macam-macam penyebab pencemaran air di laut. Rata-rata siswa mengetahui macam-macam pencemaran di Peleleangan Ikan MImbo yang terdiri dari plastik, styrofoam, dan limbah rumah tangga. Sedangkan yang paling rendah terdapat pada butir soal no. 10 yang menanyakan tentang penyebab pencemaran tanah dan solusinya. Rata-rata siswa masih belum mengetahui mengenai remediasi tanah ex-situ dan in-situ dan limbah industri sebagai penyebab pencemaran tanah.

\section{Hasil Aspek Proses Sains}

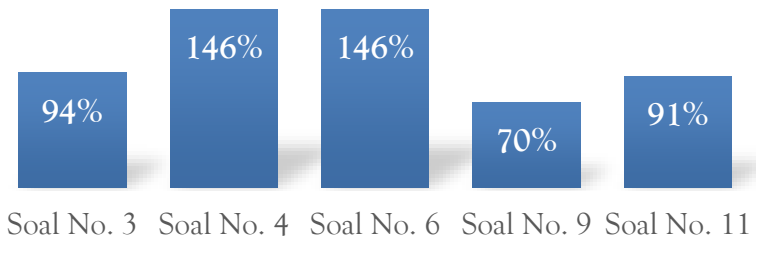

Gambar 7. Grafik presentase rata-rata hasil aspek proses sains setiap butir soal

Berdasarkan hasil rata-rata aspek proses sains tiap butir soal dapat dilihat pada gambar 7 . presentase hasil paling tinggi yaitu soal no. 4 dan no. 6. Soal no. 4 menanyakan kesimpulan fenomena yang terjadi pada kondisi ikan di laut yang tercemar, dan soal no.6 menanyakan tentang hasil pengamatan berdasarkan gambar dan pernyataan pada pencemaran sungai. Sehingga dapat disimpulkan bahwa rata-rata siswa mengetahui tentang kesimpulan kondisi ikan pada air tecemar dan mengetahui tentang fenomena yang terjadi pada sungai. Sedangkan hasil rata-rata aspek proses sains yang paling rendah terdapat pada no.9 yang menanyakan tentang langkah-langkah menyelesaikan masalah pencemaran pada sungai. Jadi, dapat disimpulkan bahwa rata-rata siswa belum mengetahui proses sians untuk mencari solusi dari masalah lingkungan di sungai.

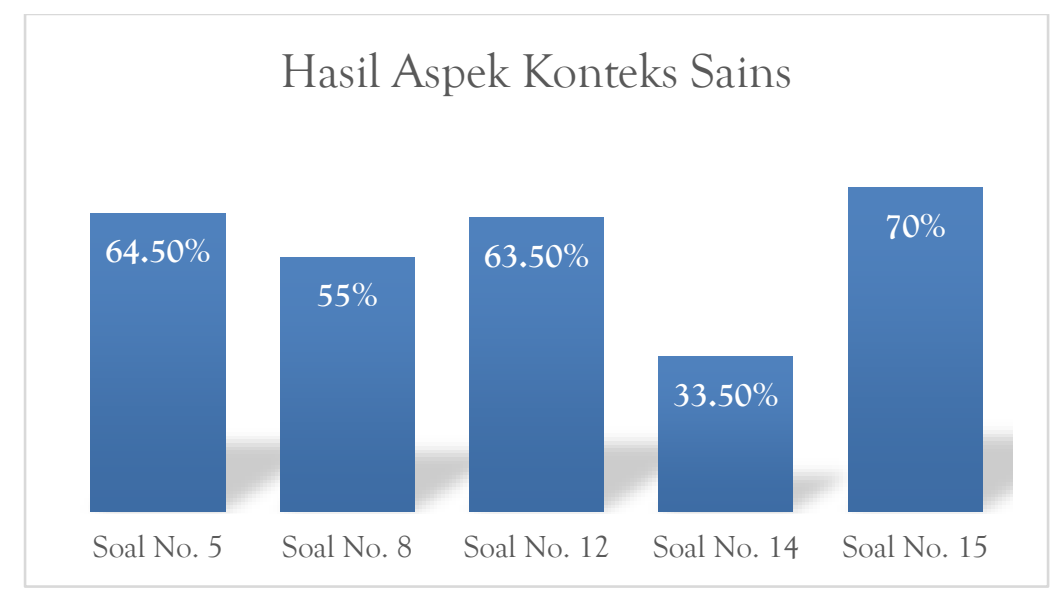

Gambar 8. Grafik presentase rata-rata hasil aspek konteks sains setiap butir soal

Berdasarkan hasil rata-rata aspek kontens sains tiap butir soal dapat dilihat pada gambar 8 . presentase hasil paling tinggi yaitu soal no.15 yang menanyakan tentang tindakan masyarakat dalam menyikapi persoalan bau bangkai ikan di pelelangan ikan Mimbo. Sehingga dapat disimpulkan bahwa rata-rata siswa mengetahui apa yang harus dilakukan untuk mencegah terjadinya pencemaran udara pada daerah pelelangan tersebut. Sedangkan hasil rata-rata aspek konteks sain yang paling rendah terdapat pada no. 14 yang menanyakan tentang cara pemerintah dalam mengelola lingkungan yang telah terjadi pencemaran udara. Sehingga dapat disimpulkan bahwa siswa belum mengetahui cara mengelola lingkungan yang telah terjadi pencemaran udara. 


\section{Simpulan}

Berdasarkan hasil penelitian analisis kemampuan siswa SMP 3 Ibrahimy pada isu lingkungan pelelangan ikan Mimbo, Kabupaten Situbondo dapat dikemukakan bahwa persentase rata-rata kemampuan literasi sains siswa pada 3 aspek masih dikatagorikan rendah yaitu aspek konten sauns (55,9\%), aspek proses sains $(54.70 \%)$, dan aspek konteks sains (57,4\%). Penelitian analisis kemampuan literasi sains ini mengharapkan adanya penelitian lanjut mengenai literasi sains dengan berbagai model atau media pembelajaran yang dapat meningkatkan literasi sains siswa.

\section{Daftar Pustaka}

Ahmad, M., J. L. Li1, P. D. Wang, \&W. N. Hozzein, \& W. J. L. (2020). Environmental perspectives of microplastic pollution in the aquatic environment: a review. Marine Life Science $\mathcal{E}$ Technology, 2(November 2020), 414-430. https://doi.org/https://doi.org/10.1007/s42995-020-00056-w

Ali, M. (2013). Prosedur dan Strategi Penelitian Pendidikan. Bandung: Angkasa.

Alimba, C. G., \& Faggio, C. (2019, May 1). Microplastics in the marine environment: Current trends in environmental pollution and mechanisms of toxicological profile. Environmental Toxicology and Pharmacology, Vol. 68, pp. 61-74. Elsevier B.V. https://doi.org/10.1016/i.etap.2019.03.001

Amalia, R., \& Yulianti, I. (2018). Identifikasi kemampuan litersi sains pada materi gerak lurus kelas X MIPA SMA di SMAN RAMBIPUJI. Prosiding Seminar Nasional Pendidikan Fisika 2018, 3(2), 184189.

De-la-Torre, G.E., Dioses-Salinas, D.C., Castro, J.M., Antay, R., Fernández, N.Y., Espinoza-Morriberón, D., \& SaldañaSerrano, M. (2020). Abundance and distribution of microplastics on sandy beaches of Lima, Peru. Marine Pollution Bulletin, 151. https://doi.org/10.1016/j.marpolbul.2019.110877

Eriksen M, Lebreton LCM, Carson HS, Thiel M, Moore CJ, \& B. JC. (2014). Plastic Pollution in the World's Oceans: More than 5 Trillion Plastic PiecesWeighing over 250,000 Tons Afloat at Sea. PLOS ONE, 9 (12). https://doi.org/10.1371/journal.pone.0111913

Jambeck, Geyer, J.R.R., Wilcow, C., Siegler, T.R., Perryman, M., Andrady, A., Narayan, R. \& Law, N. L. (2015). Plastic Waste Inputs from Land Into The Ocean. Science, 347(6223), 768-771. https://doi.org/10.1126/science.1260352

Kementerian Lingkungan Hidup dan Kehutanan. (2017). Pemantauan sampah laut Indonesia tahun 2017. Info Singkat Kajian Singkat Terhadap Isu AKtual Dan Strategis, 1-46. Retrieved from https://ppkl.menlhk.go.id/website/filebox/274/180703160900REKAP SAMPAH LAUT INDONESIA 2017

Mulu, M., Wendelinus Dasor, Y., Hudin, R., \& Tarsan, V. (2020). Marine Debris Dan Mikroplastik: Upaya Mencegah Bahaya Dan Dampaknya Di Tempode, Desa Salama, Kabupaten Manggarai, NTT. Randang Tana Jurnal Pengabdian Masyarakat, 3(2), 79-84. https://doi.org/10.36928/jrt.v3i2.404

NOAA. (2013). Programmatic Environmental Assessment (PEA) for the NOAA Marine Debris Program (MDP). 168. 
Pamungkas, M. O. A. (2016). Studi Pencemaran Limbah Cair Dengan Parameter Bod5 Dan Ph Di Pasar Ikan Tradisional Dan Pasar Modern Di Kota Semarang. Jurnal Kesehatan Masyarakat (Undip), 4(2)(ISSN: 2356-3346), 166-175.

Peeken I, Primpke S, Beyer B, Gütermann J, Katlein C, \& K. T. (2018). Arctic Sea ice is an important temporal sink and means of transport for microplastic. Nat Commun, 9 (1), 1505. https://doi.org/10.1038/s41467-018-03825-5

Pham, D. N., Clark, L., \& Li, M. (2021). Microplastics as hubs enriching antibiotic-resistant bacteria and pathogens in municipal activated sludge. Journal of Hazardous Materials Letters, 2, 100014. https://doi.org/10.1016/j.hazl.2021.100014

PISA. (2010). Assesing framework key competencies in reading, mathematics, and science.

Purwanto. (2009). Prinsip-prinsip dan Teknik Evaluasi Pengajaran. Bandung: Remaja Rosda Karya.

Putra, B. A., A. Santoso, \& I. R. (2019). Kandungan Logam Berat Seng pada Enhalus acoroides di Perairan Jepara. BULETIN OSEANOGRAFI MARINA, 8 (1), 9-16. https://doi.org/10.14710/buloma.v8i1.21378

Putrawan, I. M. (2019). A Comparative Analysis of New Ecological Paradigm (NEP), Ecosystem Knowledge, and Stduents' Self-Control Based on Gender. International Journal of Innovative Technology and Exploring Engineering, 8(ISSN: 22783075), 68-71.

Sukib, S., Muti'ah, M., Siahaan, J., \& Supriadi, S. (2020). Meningkatkan Kesadaran Bahaya Sampah Laut Melalui Pendampingan pada Masyarakat Lokasi Wisata Pantai Kuranji. Jurnal Pengabdian Magister Pendidikan IPA, 2(2). https://doi.org/10.29303/jpmpi.v2i2.343

Suprijanto, J., Senduk, J. L., \& Makrima, D. B. (2021). Penggunaan Fourier Transform Infrared untuk Analisis Mikroplastik pada Loligo sp. dan Rastrelliger sp. dari TPI Tambak Lorok Semarang. Buletin Oseanografi Marina, 10(3), 291-298. https://doi.org/10.14710/buloma.v10i3.38964

Wong, G., Löwemark, L., \& Kunz, A. (2020). Microplastic pollution of the Tamsui River and its tributaries in northern Taiwan: Spatial heterogeneity and correlation with precipitation. Environmental Pollution, 260. https://doi.org/10.1016/j.envpol.2020.113935 